\title{
HUME, CAUSATION AND TWO ARGUMENTS CONCERNING GOD
}

\section{JASON MEGILL}

\author{
Carroll College
}

\begin{abstract}
In Dialogues Concerning Natural Religion, Hume (1779/1993) appeals to his account of causation (among other things) to undermine certain arguments for the existence of God. If 'anything can cause anything', as Hume claims, then the Principle of Causal Adequacy is false; and if the Principle of Causal Adequacy is false, then any argument for God's existence that relies on that principle fails. Of course, Hume's critique has been influential. But Hume's account of causation undermines the argument from evil at least as much as it undermines arguments for theism, or so I argue. I then suggest that Hume's account of causation can be used to formulate an alternative argument against classical theism.
\end{abstract}

\section{INTRODUCTION}

Hume's (1779/1993) ingenious attack on some of the traditional arguments of natural theology has influenced many. One important aspect of Hume's critique involves his account of causation. Some of the arguments in natural theology (e.g., some versions of the Cosmological argument) rely on certain causal principles; if Hume's account of causation is true, then these causal principles - along with the arguments that rely on them - must be rejected. This paper argues that if one accepts Hume's critique of certain arguments for theism, one must also reject the most famous argument for atheism, the argument from evil. That is, Hume's account of causation undermines the argument from evil just as 
much as it undermines certain arguments for theism. This is good news for the theist. However, it also appears that Hume's account of causation can be used to formulate a novel argument against the existence of God.

In section I, I briefly discuss Hume's account of causation, including his famous claim that at least in principle, anything could be a cause of anything. In section II, I discuss the Principle of Causal Adequacy. This principle (i) was used in various arguments for theism, but (ii) is false if Hume is right about causation. In section III, I argue that Hume's account of causation undermines arguments from evil as much as they undermine arguments for theism. Given the considerable influence Hume's account of causation has had, theists might try responding to the problem of evil by appealing to Hume's account of causation. In section IV, I conclude by formulating a new Humean argument against theism.

\section{I. 'ANY THING MAY PRODUCE ANY THING'}

Hume's discussion of causation is well-known; my exegesis will be brief. Hume (1748/1975: 25) begins his discussion by drawing a distinction between two types of knowledge, (i) knowledge of 'relations of ideas' (Hume's term for analytic truths) and (ii) knowledge of 'matters of facts' (Hume's term for synthetic truths). Hume (1748/1975:25) claims that relations of ideas are 'discoverable by the mere operation of thought, without dependence on what is anywhere existent in the universe', while matters of fact 'are not ascertained in the same manner' (Hume 1748/1975). In other words, analytic truths are a priori while matters of fact are not, and so are a posteriori. Furthermore, Hume (1748/1975: 25 ) holds that 'the contrary of every matter of fact is conceivable'; given this, matters of fact are possibly false and so are not necessarily true. On the other hand, relations of ideas are not conceivably false and so are necessary. In short, Hume believes that (i) analytic truths are a priori and necessary while (ii) synthetic truths are a posteriori and contingent.

Hume (1748/1975) then analyzes the concept of causation. He discusses a number of criteria it appears that a causal relation must meet. For example, if $A$ causes $B$, then (i) $A$ and $B$ should be contiguous, (ii) $A$ should occur before $B$, and importantly, (iii) there should be a necessary connection between $A$ and $B$. For Hume, there should be a necessary connection between cause and effect because causal inferences take us beyond what we are given in the senses (Noonan 2007). When making 
a causal inference, we move 'from the observed to the unobserved' (Noonan 2007: 59), i.e., from the present to future; and the only way we could be justified in doing so is if there is a necessary connection between cause and effect. If there is no necessary connection between cause and effect, then we cannot be certain that the effect will occur even though the cause has. The problem, however, is that it appears that causal relations are not necessary, as Hume attempts to show with various arguments. For example, we can conceive of a cause occurring without its effect; this implies that causal relations cannot be necessary (assuming that conceivability entails possibility). Furthermore, Hume can find no evidence of a necessary connection between causes and effects in our experience: all we see is one event followed by another. Moreover, if we consider some object, some putative cause, in isolation, we can find no intrinsic property of the object that would tell us that the object could be a cause or what it could cause. There is no 'quality which binds the effect to cause and renders the one an infallible consequence of the other' (Hume 1748/1975: 63). That is, for Hume, if there is a necessary connection between cause and effect, we should be able to tell, a priori, what a given cause can cause (again, for Hume, necessity is associated with the a priori); since we cannot do so, causal relations cannot be necessary. But again, causal relations must be necessary if they are to warrant inferences about the future. It follows that our causal inferences are unjustified. ${ }^{1}$

The key claim for our purposes here is the following: there is no 'quality which binds the effect to cause and renders the one an infallible consequence of the other' (Hume 1748/1975: 63). There are no constraints on what can cause what; in principle, anything can cause anything.

\section{CRITIQUE OF NATURAL THEOLOGY}

The Causal Adequacy Principle claims that 'no cause can produce or give rise to perfections or excellences that it does not itself possess' (Russell 2005: Section 3). In the early modern period, this principle was used in a number of arguments for God's existence. The most famous example is Descartes's (1641/1984) trademark argument in the 3rd Meditation:

${ }^{1}$ This is, of course, an incomplete account of Hume's views on causation. For example, nothing has been said about the impossibility of giving a non-circular justification of induction. Nevertheless, this incomplete account is sufficient for our purposes here. 
Descartes has the idea of God.Given that ideas must have a cause, Descartes's idea of God must have a cause. And given the Principle of Causal Adequacy, this cause must be adequate to cause the idea of God. Only God could be an adequate cause of the idea of God; so, God must exist. Others used the Causal Adequacy Principle in theistic arguments as well. Clarke (1704/1998), for example, argues that since any effect cannot have a 'perfection' that was not in the cause, there is no way that matter could give rise to thought. So, given that the universe has a first cause, this first cause cannot be material and unthinking (for otherwise thought would be unable to arise at all); that is, the first cause is an immaterial thinking being. Others who appealed to the Causal Adequacy Principle to establish the truth of theism include Cudworth (1678/1978) and even Locke. $^{2}$

Clearly, Hume's account of causation and the Principle of Causal Adequacy are inconsistent. The Principle of Causal Adequacy places constraints on what can cause what: a cause must be sufficient or 'appropriate' in various ways to produce its effect. However, Hume's account of causation denies the existence of such constraints: anything can cause anything. If Hume's account of causation is correct, then the theistic arguments of Descartes, Cudworth, Clarke, Locke and others cannot be sound.

\section{THE PROBLEM OF EVIL}

The argument from evil is the most prominent argument for atheism; it is an argument against the existence of God, where God is understood as a being that is omnipotent, omniscient and omnibenevolent (the '3-O God'). Logical arguments from evil claim that the existence of the 3-O God is logically impossible; the combination of this being and some of the evil that exists in the actual world are inconsistent. ${ }^{3}$ Evidential arguments from evil claim that the presence of at least some of the evil

\footnotetext{
${ }^{2}$ See Russell (2008, Chapter 3) for an excellent discussion of the Causal Adequacy Principle and the role it played in various theological arguments before and during Hume's time. The principle was so closely related to theism at that time that Hume's denial of it was cited by Hume's religious critics as evidence of his religious scepticism.

${ }^{3}$ For instance, one might make the argument: assume that the 3-O God exists. But this being would know when an innocent child is dying of leukaemia (it knows everything), it should want to prevent the death (it is all-good, after all) and it has the ability to do so (it is all-powerful). So no innocent children should die of leukaemia. Yet they do. The
} 
in the actual world lowers the epistemic probability that the 3-O God exists. ${ }^{4}$ Of course, theists have tried to respond to the problem of evil in various ways. Perhaps the actual world is the best possible world (Leibniz (1710/1951))? Perhaps there is no best possible world; God cannot be faulted for not actualizing something that cannot be actualized (Schlesinger (1964; 1977) and Forrest (1981))? Perhaps the evils in our world serve a purpose; e.g., they develop our souls (Hick 1966)? Perhaps God is not obligated to create the best possible world (Adams 1972)? Perhaps much of the evil in the actual world is a consequence of our free will (see Plantinga 1974; 1977)? Perhaps there is a reason why evil exists, but we simply do not know it (see Wykstra 1984)? And so on.

But, oddly enough, Hume could be an unlikely ally in the theist's effort to account for the existence of evil: Hume's account of causation and the logical problem of evil, at least, are inconsistent. Assume, as Hume's account of causation claims, that anything can cause anything. In logical notation, this can be written: (1) $\forall \mathrm{x} \forall \mathrm{y} \diamond$ Cause( $\mathrm{x}, \mathrm{y}) .{ }^{5}$ But also suppose that it is contradictory, and so logically impossible, for the 3-O God to cause our universe: given some of the gratuitous evil in the actual world, an all-powerful, all-knowing and all-good being would not and could not have caused this world. That is, (2) $\neg \diamond$ Cause(God, our universe). But with substitution (or universal elimination) on line (1), one can infer: (3) $\diamond$ Cause(God, our universe). (2) and (3) contradict one another. So, not both (1) and (2) can be true. We must reject either (i) Hume's account of causation (or at least key parts of it) or (ii) the logical problem of evil. So, accepting Hume's critique of natural theology, or rather that part of the critique that depends on his analysis of causation, while simultaneously endorsing the logical problem of evil, is problematic. ${ }^{6}$ And perhaps more importantly, the theist has another response to the logical problem of evil. We can agree with Hume that anything can cause anything. But then the 3-O God could cause our universe.

contradiction implies that our initial assumption is false: the 3-O God does not exist. For the logical argument from evil, see Mackie (1955) and McCloskey (1960).

${ }^{4}$ For the evidential argument from evil, see Rowe $(1978 ; 1979 ; 1988 ; 1996)$ and Draper (1989).

5 Though one might want to add the proviso that $\mathrm{x} \neq \mathrm{y}$, to avoid cases in which an entity causes itself.

${ }^{6}$ It is not difficult to find philosophers who think both (i) that Hume's critique of, say, the Cosmological argument is a serious one and (ii) that the problem of evil provides some evidence for atheism. Sobel (2004) is but one example. 
One might wonder if evidential arguments from evil are also inconsistent with Hume's account of causation. They are. Again, evidential arguments claim that the existence of some of the evil in the actual world lowers the (epistemic) probability that the 3-O God exists. But recall that Hume claimed that anything can cause anything. There is nothing intrinsic to a cause that suggests what it could cause. So, it appears that not only can anything cause anything, but the probability that any $x$ could cause a given $y$ is the same. Just as we cannot look at a putative cause and determine, a priori, what it could cause, we cannot look at a putative cause and determine, a priori, what it is likely to cause either. Therefore, we should not be able to consider the concept of the 3-O God and determine - a priori - what it could likely and unlikely cause. The 3-O God could cause any universe - no matter how wonderful or horrific - with equal probability, if Hume is correct. Likewise, for Hume, we cannot determine, a priori, what could cause, or even likely could cause, a given effect. But then we cannot determine, a priori, what caused a given effect (for if we could, then there must be some connection between the nature of a cause and what it could cause in principle, and there is no such connection). So, we cannot examine the actual world, and infer that - given the evil that exists - it is less likely that it was caused by the 3-O God.

\section{A HUMEAN ARGUMENT AGAINST CLASSICAL THEISM}

Even though Hume's account of causation undermines the argument from evil, it appears it can be used to formulate a different argument against classical theism (or against the existence of the 3-O God). While the claim that anything can cause anything makes it possible that the God of classical theism caused our universe, it also makes it highly improbable that the God of classical theism caused our universe.

Consider the following argument: first, suppose - as is suggested by Hume's account of causation - that anything can cause anything with equal probability. Then, grant to the theist that the universe has a cause. And consider a set $S$ of, say, 100 properties. We stipulate that $S$ contains three properties: omnipotence, omniscience, and omnibenevolence. As for the other 97 properties in $S$... one can pick just about any properties one likes, so long as they are not logically inconsistent with any of the 3-O properties. One can form subsets of $S$ by selecting properties in $S$. For 
example, one subset will contain all three of the 3-O properties and no other properties; some subsets will contain the 3-O properties along with other properties in $S$ (so, e.g., a set will contain the 3-O properties plus, say, property 37 , whatever it is); some subsets might contain none of the 3-O properties; and so on. One can think of each subset as corresponding to a being; for instance, a subset that contains the 3-O properties might correspond to the 3-O God. But if it is correct that anything can cause anything, then any subset of properties in $S$ is just as likely to correspond to a being that could cause the universe as any other. So, one might ask, 'what is the probability that the cause of the universe has all three of the 3-O properties?' Of course, the probability that the being will be omnipotent is $1 / 100$. The probability that this omnipotent being will also be omniscient is $1 / 99$. And the probability that this omnipotent and omniscient being will also be omnibenevolent is $1 / 98$. So the probability that the being will have all three of these divine attributes - and so the probability that the cause of the universe is a being that can be called the God of classical theism - is $1 / 100{ }^{\star} 1 / 99{ }^{\star} 1 / 98$. That is, 0.00000103 . It is extremely improbable that the God of classical theism caused the universe, at least given Hume's account of causation.

The theist might respond that the calculation is too crude: it has been argued, for example, that an omnipotent being will also be omniscient. ${ }^{7}$ If so, then given that the being is omnipotent, the probability that it will also be omniscient is 1 . This would indeed raise the probability that the $3-\mathrm{O}$ God caused our universe, but it would still only be $1 / 100 * 1 / 98$, and so would still be very low; it would be 0.0001 , to be precise. Perhaps the theist can appeal to the doctrine of divine simplicity? If divine simplicity is true, and so all of God's properties are indivisible, and so are unified in some sense, then perhaps if a being has one of the divine attributes, it has all of them? This would greatly increase the odds in favour of the theist ... but they would still only be $3 / 100$, and so $1 / 33$. These are still rather poor odds. And there do not seem to be too many other possible responses: the theist might argue that an omnipotent being could give itself other properties. So an omnipotent being could make itself all-knowing and all-good. But even here, the odds are only $1 / 100$. The theist might argue that there are not even 100 properties ... if not, then $S$ will have to be smaller, so the odds that the God of classical theism caused the universe will rise? But surely there are at least 100 properties. Of course, the theist

\footnotetext{
${ }^{7}$ See, for instance, Megill and Mitchell (2009).
} 
could reject Hume's account of causation; indeed, this appears to be the most promising strategy.

In sum, Hume's account of causation has been taken by many to undermine some of the traditional arguments for God's existence. It does. But what some have failed to notice is that it also undermines the argument from evil. Hume's account of causation entails that the 3-O God could have caused our universe. However, Hume's account of causation can be used to formulate a different argument against classical theism. If the above arguments are sound, there are different strategies the theist and atheist might adopt. The theist might reject Hume's account of causation and search for other responses to the problem of evil; this might also make it possible to appeal to some of the traditional arguments for theism that Hume's account of causation undermines. Or the theist might accept Hume's account of causation, thereby solving the problem of evil; but the theist would then need to find some response to the alternative argument against theism just discussed. On the other hand, the atheist might endorse Hume's account of causation, thereby undermining many traditional arguments for God's existence and making it possible to appeal to the alternative argument against theism just discussed; they would have to abandon the argument from evil though. Or the atheist might reject Hume's account of causation and keep the argument from evil.

\section{BIBLIOGRAPHY}

Adams, R.M. 1972. 'Must God Create the Best?', Philosophical Review, 81(3): 317-332

Clarke, S. 1704/1998. A Demonstration of the Being and Attributes of God. Edited by E. Vailati (Cambridge: Cambridge University Press)

Cudworth, R. 1678/1978. True Intellectual System of the Universe, 2 Vols. (London, 1678; reprinted by New York \& London: Garland)

Descartes, R. 1641/1984. Meditations on First Philosophy in The Philosophical Writings of Descartes, Volume 2. Translated by John Cottingham, Robert Stoothoff, and Dugald Murdoch (Cambridge: Cambridge University Press), pp. 1-62

Draper, P. 1989. 'Pain and Pleasure: An Evidential Problem for Theists', Nô̂s, 23: $331-350$

Forrest, P. 1981. 'The Problem of Evil: Two Neglected Defenses', Sophia, 20: 49-54 Forrest, P. 1996. 'A Speculative Understanding of Evil', in God Without the Supernatural (Ithaca: Cornell University Press) 
Hick, J. 1966. Evil and the God of Love (New York: Harper and Row)

Hume, D. 1748/1975. Enquiries Concerning Human Understanding and Concerning the Principles of Morals, 3rd Edition, edited by L.A. Selby-Bigge and P. H. Nidditch. (Oxford: Oxford University Press)

Hume, D. 1779/1993. Dialogues Concerning Natural Religion in Dialogues and Natural History of Religion. Edited by J. A. C. Gaskin (Oxford \& New York: Oxford University Press), pp. 29-130

Leibniz, G. 1710/1951. Theodicy (New Haven: Yale University Press)

Mackie, J.L. 1955. 'Evil and Omnipotence', Mind, 64: 200-212

McCloskey, H.J. 1960. 'God and Evil', Philosophical Quarterly, 10: 97-114

Megill, J and Mitchell, J. 2009. 'A Modest Modal Ontological Argument', Ratio, 22.3: $338-349$

Noonan, H. 2007. Hume (Oxford: Oneworld Publications)

Plantinga, A. 1974. The Nature of Necessary (Oxford: Oxford University Press) Plantinga, A. 1977. God, Freedom, and Evil (Grand Rapids, MI: Eerdmans)

Rowe, W. L. 1978. Philosophy of Religion: An Introduction (Encino, CA: Dickenson Publishing Company)

Rowe, W. L. 1979. 'The Problem of Evil and Some Varieties of Atheism', American Philosophical Quarterly, 16: 335-41

Rowe, W. L. 1988. 'Evil and Theodicy', Philosophical Topics, 16: 119-32

Rowe, W. L. 1996. 'The Evidential Argument from Evil: A Second Look', in The Evidential Argument from Evil. Edited by D. Howard-Snyder (Bloomington: Indiana University Press)

Schlesinger, G. 1964. 'The Problem of Evil and the Problem of Suffering', American Philosophical Quarterly, 1: 244-7

Schlesinger, G. 1977. Religion and Scientific Method (Boston: D. Reidel)

Sobel, J. H. 2004. Logic and Theism: Arguments For and Against Beliefs in God (New York: Cambridge University Press) 